Сања В. Раденковић

\title{
КАИЗЕН КОНЦЕПТ
}

Свет је јапанску културу скоро увек сматрао јединственом, што се углавном приписује специфичном географском положају Јапана и националном карактеру Јапанаца. Било да говоримо о самој земљи или о односима са странцима, организовању предузећа или сарадњи са страним компанијама, не можемо пренебрегнути чињеницу да је најснажнији траг на јапанску културу и менталитет, који се осећају све до данашњих дана, оставила изузетно дуга војна владавина.

Утемељење самураја као владајуће класе извршило је дубок утицај на културу и психологију јапанског народа, што ће имплицитно утицати на судбину Земље излазећег сунца. Значајан сегмент јапанске културе представља филозофија Каизен која прожима све поре јапанског друштва. На пословном плану, као и у свакодневном животу, концепт Каизена је толико дубоко инфилтриран у начин размишљања запослених, заправо свих житеља Јапана, да они често и нису свесни да делају према начелима Каизен филозофије, те да им је она усађена у процесе предлагања и доношења одлука. Овакав начин размишљања и рада заправо јесте оно што издваја јапанске компаније у односу на друге у свету. Због доказаног успеха јапанских предузећа која су применила Каизен филозофију, она је имплементирана у организационе системе компанија широм света као средство унапређења производних вредности, али и унапређења морала и безбедности запослених. Кроз различите примере успешне примене Каизен филозофије увиђамо да је константно унапређење аксиом јапанског успеха.

Кључне речи: Каизен, јапанска филозофија, култура, производња, менталитет, самураји, решавање проблема, константно унапређење, компаније у Европи и Америци, постизање резултата.

Да бисмо разумели каизен начин размишљања, морамо пре свега да се позабавимо јапанском културом. Култура Јапана је резул- 
Сања В. Раденковић, Милица Д. Јотов, Кристина 3. Њаради

тат историјског процеса који почиње с таласима усељавања становништва пореклом са континента Азије и острва Пацифика, а затим с јаким културним утицајем из Кине и дугим раздобљем изолације од остатка света све до касног деветнаестог века, када Јапан прима велики утицај страних култура и постаје економски снажан у периоду након завршетка Другог светског рата. Управо због тога се Јапан разликује од других азијских култура. У Јапану, међуљудски односи су под јаким утицајем идеја «части», «обавеза» и «дужности», заједно познатих као гири.

У Јапану постоји Бушидо код, који потиче од самураја (Дајдођи $\left.{ }^{1}\right)$ по коме је часно бити добар следбеник. Иако су самураји као ратници у Јапану готово изумрли и њихова улога није више иста, традиција под именом Бушидо се наставља.

Када бисмо објашњавали овај код, сложили бисмо се да је то филозофија живота, систем вредности и принципа којима се људи руководе. Самураји су носили мачеве зато што је за тим постојала реална потреба и требало је заштитити живот господара. Од њих се очекивало да служе господару, следе га и свој живот заложе за њега. Захтеви савременог друштва и даље имају потребу за Бушидо кодом, само што се он испољава на другачији, помало необичан начин. Сада радници, односно запослени постају самураји који чувају углед компаније за коју раде и за коју су на крају, спремни да дају и живот. Феномен «Кароши» 過労死 (смрт услед претераног рада) типичан је за јапанско друштво и представља у светском пословном контексту јединствен пример посвећености раду до екстремног само жртвовања које недвосмислено упућује на постулат самурајског кодекса части - харакири. Радници су у Јапану крајње лојални својим претпостављенима. Једном када се запосле у компанији, Јапанци се посвећују компанији, градећи полако свој пут. У јапанским фирмама из редова запослених односно обичних следбеника полако се напредује по хијерархијској лествици до менаџерских позиција. Проверавање капацитета за лидерство кроз пут следбеништва уобичајен је пут напредовања у јапанском менаџменту. Заправо, за добијање менаџерске позиције, осим одговарајуће школе, потребно је да запослени раде на различитим позицијама, уче се различитим пословима, савлађују

1 Дајдођи, J. (2008). Бушидо, кодекс самураја. Београд: Бабун 
бројне вештине, упознају се са свим хијерархијским нивоима, не само пословним већ и лингвистичким (савладавањем хонорифичног говора), као и функционисањем организације у целини. Заузврат, менаџери су врло одговорни и коректни према следбеницима (запосленима), у складу са јасно дефинисаним односом ојабун-кобун. Постоји пуно узајамно поверење (Хасегава $\left.{ }^{2}\right)$, као и двосмерна одговорност надређених и подређених.

Овакав однос према компанији и раду вуче корене из породице, начина васпитања, самурајског кодекса части, као и културе читаве нације. Када говоримо о култури, недвосмислено можемо рећи да су и економија и социјални односи део културе, али у овом случају говоримо о вишем и сложенијем делу укупне културе савременог друштва. Овај став произилази из чињенице да је рад основа културе, те да култура, истовремено, унапређује и трансформише рад. Њихов узајамни однос, повезаност, условљеност и подстицај представљају основу стваралаштва и напретка сваког колективног субјекта у друштву и друштва у целини. Да би аутори рада показали утицај јапанске културе на однос према раду, пре свега ће се позабавити односима у породици и друштвеним вредностима које поштују представници јапанског друштва.

Централно место породице у већини источноазијских земаља, као централне вредности конфучијанизма, допринело је бржем развоју породичних предузећа и породичног бизниса. “Слика породице као микрокосмоса државе и идеала државе као проширене породице, указује да је породична стабилност суштински важна за политички живот и да је суштински важна улога државе у осигурању органске солидарности у породици"(Ту Вејминг $\left.{ }^{3}\right)$. Оно што је допринело културној трансформацији и постизању успеха у Јапану јесте њихова спремност да се учи од других и да се цене резултати и успех других. Јапанци су, прихватајући знања и искуства са запада, превазишли учитеље и направили такве резултате који су довели до модер-

2 Хасегава, К. (1986). Japanese-style management. Tokio, New York and San Francisko, Kondasha International Ltd.

3 Ту Вејминг (2004), Многостране модерности: Прелиминарно испитивање импликација источноазијске модерности, у: L.E.Harison, S.P.Hantington, «Култура је важна», Плато, Београд, стр. 411 
низације привреде, економије и друштва у целини. Како наглашава Ту Вејминг, таква “позитивна идентификација са Западом”, као и такав “модел креативне адаптације” који су учинили да дође до потпуног реструктурирања економије и начина живота, те брзог успона и напретка источноазијских држава, “нема преседана у људској историји”. Кроз адаптацију, идентификацију, учење, прихватање развијеног и напредног дошло је до трансформације традиционалне културе конфучијанизма и истицања нових вредности: спремност да се учи од других; оданост раду, заједници; жеља за новим и вишим постигнућима; штедљивост, марљивост, такмичење. Управо учење, тежња ка унапређењу, постизању бољих резултата довело је до тога да сада западне земље, желећи да постигну резултате које је Јапан направио, проучавају каизен филозофију која заправо представља окосницу јапанског пословања.

Каизен рефлектује филозофију живота према којој из дана у дан треба да будемо све бољи. То је континуирани напредак у свим аспектима живота. У пословном свету означава континуирано побољшање свих пословних функција - од производње до управљања. Захваљујући овом приступу, јапанска привреда је после Другог светског рата успела да се избави из расула у које је запала, а данас чини саставни део пословања многих компанија широм света. Каизен представља непрестано побољшање. Каизен филозофија полази од претпоставке да наш начин живота, било да се ради о радном, друштвеном или приватном животу, заслужује да га стално унапређујемо (Масаки $\left.И^{4}\right)$.

После другог светског рата јапанске компаније су пред собом имале тежак задатак. Морале су поново да се „роде“ па је каизен као филозофија и концепт константног напретка, утицао на увођење промена које касније постају начин живљења. Овај концепт, како аутор Масаки каже подразумева:

- Оријентацију ка потрошачу

- Свеобухватну контролу квалитета (СКК)

- Роботику

• КК кружоке (кружоци контроле квалитета)

- Систем предлога

4 Масаки И., Каизен - Кључ јапанског пословног успеха, Моно и Мањана, Београд, 2008., стр. 31). 
- Аутоматизацију

- Дисциплину на радном месту

- Свеобухватно продуктивно одржавање

- Канбан

- Побољшање квалитета

- Just - in - time (Баш-на-време) концепт

- Нулти шкарт

- Активности малих група

- Кооперативне односе између радника и менаџмента

- Побољшање продуктивности

- Развој нових производа

Сваки од наведених сегмената је изузетно важан за постизање коначног циља, али ће се аутори, у овом чланку бавити темом објашњавања појма каизен уз представљање чињеница које показују доминацију јапанске привреде.

40 година након Другог светског рата је Јапан постао економска велесила. Прошао је кроз 5 фаза адаптације како би постао конкурентан у разним производним областима.

Пет фаза адаптације:

1. Велики увоз технологије из САД-а и Европе

2. Раст продуктивности у дотад незабележеним размерама

3. Увођење програма побољшања квалитета на нивоу земље, инспирисаног идејама др Диминга и др Џурана ${ }^{5}$ из САД-а

4. Висок степен производне флексибилности

5. Мултинационализам

Прихватањем иностраних технологија, јапанске компаније су достигле висок ниво продуктивности и квалитета. Овде треба навести да само прихватање иностраних технологија није било довољно за постизање резултата. Уз каизен технологију, јапанске компаније су биле способне да се брзо прилагоде измењеним потрошачким и тржишним захтевима.

П. Ф. Дракер ${ }^{6}$, истакнути аутор савременог доба у развоју менаџмента каже: “Менаџмент је независан од власништва, положаја и моћи. Менаџмент је професионалан, то је функција, дисциплина и

5 E.W.Deming i J.M.Juran - почињу да држе семинаре у Јапану од 1950. године 6 Дракер, П. (2006). Мој поглед на менаџмент. Нови Сад: Asee Books 
Сања В. Раденковић, Милица Д. Јотов, Кристина 3. Њаради

задатак који треба урадити, а менаџери су професионалци који менаџмент спроводе у праксу.“

Данас се сусрећемо са различитим теоријама менаџмента и поред тога што менаџмент као научна дисциплина егзистира већ више од седамдесет година. Разлози за постојање ових различитих схватања и теорија леже у томе што се дефиниција менаџмента временом обликовала под утицајем различитих фактора (технологије, економије, друштва, политике и глобализације пословања).

У Вебстеровом речнику, реч менаџмент има четири основна значења:

- Професија или вештина управљања,

- Разумно коришћење средстава и начина остварења (достизања) неког циља,

- Капацитети вођења способности извршавања,

- Колективни орган који у предузећу обавља функцију вођења, наређивања, управљања и руковођења.

Једну од најпопуларнијих дефиниција менаџмента дала је Мери Паркер Фоле ${ }^{7}$ која гласи: „Менаџмент је вештина обављања послова преко других људи."

Може се закључити да је менаџер неко ко ради са и преко других људи координирајући активности везане за посао, тако да се оне обаве ефикасно и ефективно, како би постигао организационе циљеве. Каизен има снажан утицај на менаџмент у Јапану и може се рећи да његова суштина која се односи на континуирано унапређивање преставља императив за менаџере. Пре свега, јапански менаџери настоје да одрже постојеће технолошке, менаџерске и оперативне стандарде, а затим да осмишљавају и спроводе активности које ће довести до побољшања постојећих стандарда односно успостављања виших. Каизен истиче свест о проблемима и њихову идентификацију поставља као основ за побољшање квалитета и продуктивности. С обзиром да је квалитет нешто што се може тумачити на различите начине требало би поћи од претпоставке да је то свакако нешто што може бити побољшано. Јапански кружоци квалитета су, пре свега, усмерени на

7 Мери Паркер Фолет из књиге (Лончаревић, Машић, Ђорђевић-Бољановић, 2007:17) 
области трошкова, безбедности и продуктивности, што као резултат даје побољшање услова рада на конкретном радном месту.

Као што су аутори већ навели, каизен стратегија је најважнији концепт јапанског менаџмента и кључ јапанског пословног успеха.

Када говоримо о каизену, говоримо о малим променама, али када се оне примене на стратегију, онда су то велике стратешке промене. Сваки запослени сваког радног дана треба учинити неко добро дело, односно унапредити свој радни процес и на тај начин дати скромни, али значајни допринос својој компанији и шире - својој земљи. При томе, каизен инсистира на психофизичком здрављу запослених, тако да нема ни говора о њиховој експлоатацији у било ком облику.

Имплементација каизена је процес који тече у два смера: одозго на доле и одоздо на горе. У оквиру “topdown” процеса горњи менаџерски слој иницира и подстиче увођење, поставља визије и дефинише циљеве, проверава напредак у примени и постизање циљева, у конфликтним ситуацијама посредује, смирује и одлучује. Док се приликом "bottom-up" процеса наглашава да су сви радници одговорни за примену каизена и стално побољшање, сугестијама се активно укључују у унапређење квалитета рада у фабрици или компанији.

Каизен концепт подразумева постојање система предлога које се односи на то да радници вишим нивоима менаџмента дају своје предлоге и идеје које би могле допринети унапређењу пословања. Такође, од надређених се очекује да што више подстичу раднике да дају предлоге. Није неуобичајено да се број поднетих предлога исписује по зидовима конкретног радног места како би се подстакао такмичарски дух између радника и група (Масаки И$^{8}$ ). Након усвајања одређеног предлога мењају се и стандарди у даљем пословању. Ове промене радници много лакше прихватају из разлога што промене настају захваљујући њиховим предлозима, а осећање важности које имају због прихватања њихових предлога је непроценљиво.

Још једна од покретачких снага одлучног наступа јапанских компанија јесте јака домаћа конкуренција. Усредсређујући се на цену, квалитет и услуге, компаније побољшање схватају као непрекидан процес и тиме настоје да остану конкурентни како на домаћем тако и на иностраном тржишту. Како побољшање процеса претходи побољ-

8 Масаки И., Каизен - Кључ јапанског пословног успеха, Моно и Мањана, Београд, 2008., стр. 41). 
Сања В. Раденковић, Милица Д. Јотов, Кристина 3. Њаради

шању резултата, каизен промовише процесно оријентисано мишљење за разлику од праксе у западним земљама где се активности менаџера усмеравају на резултате (Масаки ${ }^{9}$ ).

\section{КАИЗЕН МЕНАЏМЕНТ}

Већ смо навели да је каизен програм усмерен ка свеобухватном побољшању. Није ограничен само на квалитет, већ и на побољшање свих активности компаније.

Када се каизен примењује као свакодневни процес, сви у компанији морају бити укључени, од извршног директора преко менаџмент тима до запослених. Сврха каизена је да се елиминише отпад (или муда на јапанском) који настаје у компанији. То се може односити на лоше управљање временом, организацију канцеларија или друге методе које се оцене као неефикасне, при чему се креирају нове могућности. Неке компаније одржавају «Каизен окупљања» где менаџери и запослени раде заједно како би детаљно ревидирали постојеће стандарде и размотрили начине за њихово унапређење. Када се постигне ефикаснији и супериорнији систем он бива стандардизован и интегрисан у тренутну политику, правила и стандардне оперативне процедуре. Спровођење каизена на радном месту подразумева тежњу ка променама на постојећим стандардима пословања кроз разбијање сваког процеса, детаљну анализу, праћење резултата и прилагођавања у складу са уоченим недостацима.

Значајно је нагласити неопходност да се оберучке прихвати промена на радном месту, јер иста води ефикаснијем раду и побољшању процеса. Радници у западним земљама много израженије показују отпор промени док се у Јапану иста сматра добродошлом. Такође, због система доживотног запослења производни радник у Јапану нема осећај угрожености. Стога Јапанци немају ништа против да неко од колега уради њихов део посла и обратно. Стечена знања, вештине и искуства радо преносе на колеге чиме помажу стварање солидне и квалификоване радне снаге. Хомогеност јапанског друштва и изузетна мотивисаност за рад су један од разлога што у Јапану менаџмент представља

9 Масаки И., Каизен - Кључ јапанског пословног успеха, Моно и Мањана, Београд, 2008., оп.цит. стр. 42 
својеврсну подршку радницима. Веома је важна двосмерна комуникација како би се смањио јаз између радника и тимова менаџера, што изискује спремност на прилагођавање обе споменуте групе.

У јапанским компанијама се још од пре 60 година охрабрује формирање малих група међу радницима.

Каизен је стратегија која захтева непрекидне напоре да би се постигао напредак и у томе учествују сви у организацији и менаџери и радници.

1980-тих, технике менаџмента које су се фокусирале на учествовање радника и јачање преко тимског рада и интерактивне комуникације није било ништа ново у свету, али су Јапанци такве методе многе боље спровели и имплементирали од других. Тада су Јапанци хтели да буду познати у свету, такмичили су се са другим земљама и показали већу посвећеност филозофији непрекидног напретка од западњачких компанија. Такву филозофију су Јапанци назвали каизен.

Он користи здрав разум и он је такође научна метода која користи контролу квалитета као и да се његови менаџери и радници фокусирају да нема грешака, робе са грешком. То је таква филозофија да никада не можемо бити задовољни оним што смо постигли прошле године или прошле недеље.

Суштина каизена је да људи који раде одређене задатке су и највише квалификовани, упознати са тим задатком. Поред тога, тимски рад подстиче иновацију и промену, а тако што сви радници из различитих слојева учествују, имагинарни зидови организације нестају и праве места за продуктивни напредак.

Каизен подразумева да се посао тиче свих. Каизен не види људе као проблем, већ ставља акценат на процес. Радници, односно запослени у оквиру једног производног процеса могу да га побољшају тако што ће разумети како се њихови послови уклапају у тај процес и тако што ће га променити.

\section{Закључак}

Савремени услови пословања донели су глобализацију светског тржишта, а свакодневне промене које настају услед континуираног развоја информационих технологија повећавају захтеве потрошача и 
Сања В. Раденковић, Милица Д. Јотов, Кристина 3. Њаради

тако врше константан притисак на све учеснике на тржишту. Неизвесност понуде и потражње услед глобалне рецесије, скраћење животног циклуса производа, умрежавање све већег броја учесника у комплексне мултинационалне компаније, само су неки од фактора који су променили правила игре на светском тржишту. С обзиром на чињеницу да ови огромни и сложени пословни системи практично владају највећим делом светског тржишта, јасно је да сви учесници, процеси и активности у њима морају да функционишу беспрекорно, како би њихов крајњи циљ, постизање сатисфакције и лојалности крајњег потрошача успешније од конкуренције, уз истовремено постизање највеће могуће профитабилности организације, био испуњен.

Да би било која организација на глобалном тржишту уопште опстала, а затим и успешно пословала, потребно је створити максималну посвећеност свих њених чланова. Запослени који су задовољни својим послом, у највећем броју случајева демонстрираће то своје задовољство лојалношћу организацији у којој раде. Посвећеност ће се огледати у већем залагању да се пословне активности обаве на највишем нивоу и да се код клијената те организације такође постигне задовољство и оданост, што ће у крајњем исходу организацији донети позитивне пословне резултате. Успех организације ће, опет, утицати позитивно на запослене, који ће поред материјалне сатисфакције, бити задовољни чињеницом да је тај успех и њихова заслуга, што ће многима од њих донети општу добробит и у приватном животу. Задатак менаџмента је да мотивише запослене и да у њима пробуди осећај посвећености, припадности и лојалности организацији.

У овом излагању аутори рада су објаснили колико примена каизена утиче на побољшање пословања компанија, али исто тако колико треба да се промени начин размишљања свих нас. "Порука каизена” је да ниједан дан у компанији не сме проћи без побољшања.

Каизен је заснован на веровању да свако људско биће може допринети побољшању радног места. Али пре свега каизен је начин размишљања. Када га прихватимо као сопствено, почећемо да га примењујемо и резултати ће доћи и пре него што очекујемо. Компаније које су промениле своју корпоративну културу, људи који су променили културу свог рада и живљења, већ су допринели променама и одличним резултатима. Аутори овог рада се надају да ће и у Србији више бити оних који ће препознати значај увођења каизена и да ће се након тога видети резултати, а наше компаније постати конкурентне онима из развијених земаља. 


\section{Литература}

Дајдођи, J. (2008). Бушидо, кодекс самураја. Београд: Бабун.

Дракер, П. (2006). Мој поглед на менаџмент. Нови Сад: Asee Books

Хасегава, К. (1986). Japanese-style management. Tokio, New York and

San Francisko, Kondasha International Ltd.

Масаки И., Каизен - Кључ јапанског пословног успеха, Моно и

Мањана, Београд, 2008

Мери Паркер Фолет из књиге (Лончаревић,Машић,ЂорђевићБољановић, 2007:17)

Ту Вејминг (2004), Многостране модерности: Прелиминарно испитивање импликација источноазијске модерности, $\mathrm{y}$ : L.E.Harison, S.P.Hantington, «Култура је важна», Плато, Београд

Sanja V. Radenković

Milica D. Jotov

Kristina Z. Njaradi

\section{Summary}

\section{KAIZEN CONCEPT}

Kaizen is a Japanese word meaning continuous improvement. It is made up of two characters in Japanese: kai, which means 'change,' and 'zen,' which means 'good.' In his Kaizen: The Key to Japan's Competitive Success published in 1986 that introduced Kaizen to the Western corporate world, Masaaki Imai defined it as: "a means of continuous improvement in personal life, home life, social life, and working life. At the workplace, kaizen means continuous improvement involving everyone - managers and workers. Kaizen business strategy involves everyone in an organization working together to make improvements without large capital investments." (Imai, 1986) Managers are encouraged to improve the efficiency of existing infrastructure instead of investing in more of the same. "And that," says Imai, "can happen only if you are familiar with every inch of your gemba (workplace)". The objectives of kaizen include eliminating waste or activities that add cost but not value, just-in-time delivery, production load leveling of amount and types, standardized work, paced moving lines and right-sized equipment. Basically, kaizen takes processes, systems, products, and services apart then rebuilds them in a better way. Kaizen goes hand-in-hand with the quality control. Kaizen does not view problems as negative but rather sees them as positive opportunities for improvement. 
It's used to describe a company's culture where everyone, from the CEO to the front desk workers, regularly evaluate his or her work and think of ways to improve it. The concept is that small steps on a regular basis will lead to large improvements over time. The philosophy first appeared when several Japanese businesses, shortly after World War II, embraced the idea that doing things the way they've always been done should be changed in a way which would make them more competitive. Inspired by western competitors and manufacturing methods, kaizen came to be synonymous with company's strong efforts to improve and intelligently streamline business practices and manufacturing methods while simultaneously respecting the product, craft, or the people involved in making it.

The complete implementation of Japanese style management and human relations would probably be unsuccessful in America or some other countries, including Serbia because of cultural differences. The transfer of some Japanese aspects, such as worker participation in decision making, would likely provide some improvement to American and Serbian companies without disturbing cultural traditions.

For most American and Serbian companies kaizen means a significant change in the corporate culture. This is the key. The attitudes of employees from top management down to new hires will need to be changed. Kaizen needs to become something all employees do because they want to, and because they know it is good for them and for the company. It can not be something employees do because management dictates it to be done. Successful executives must learn to apply the concept of kaizen, which means making simple, common-sense improvements and refinements to critical business processes. The result: greater productivity, better quality, and higher profits achieved with minimal cost, amount of time and effort invested.

Key words: Japanese culture, philosophy, productivity 